\title{
NEW TRENDS AND CHALLENGES FOR ENERGY GEOGRAPHIES: INTRODUCTION TO THE SPECIAL ISSUE
}

\author{
Bohumil FRANTÁL, Martin J. PASQUALETTI, Dan VAN DER HORST
}

In 1961, the Canadian geographer John D. Chapman recognized the rapid growth in demand for inanimate energy and the role geographers could be playing in explaining its patterns and importance in the growing world economy (Chapman, 1961). Fifty years later, Karl Zimmerer (2011) introduced a Special Issue of the Annals of the Association of American Geographers by noting that not only had Chapman's prediction come true but that geographers were studying even a wider spectrum of energy challenges than Chapman could ever have imagined (see e.g. Dorian et al., 2006; Florini, Sovaccol, 2009).

Many of those energy challenges were underscored at last year's G20 summit in Saint Petersburg, Russia. Particular attention was paid to four concerns considered as crucial for global energy (OECD, 2013): phasing out fossil fuel subsidies (which encourage wasteful consumption, disproportionately benefit wealthier countries and sectors, and distort energy markets); price volatility (understanding and reducing temporal fluctuations and regional differences in commodity prices); market transparency (a necessity for accurate and timely energy data); and - last but not least - options of mitigating climate change (as the source of twothirds of global greenhouse-gas emissions, the energy sector is crucial for achieving any climate change goals).

By 2035, the world is projected to consume one-third more energy than today, while electricity demand should increase even by more than two-thirds (IEA, 2013). The centre of gravity of global energy demand will move decisively towards emerging economies such as China, India or Brazil, which should account for more than $90 \%$ of net energy demand growth. At the same time, however, it is estimated there will still be one billion people without access to electricity and 2.7 billion without access to clean cooking fuels in 2035, mostly in Asia and sub-Saharan Africa (ibid.). The current global energy market is characterized by rising differences in regional energy prices (depending on the availability of domestic resources and regional position within international energy flows), which have led to major shifts in energy and overall trade balances, as well as to energy expenditures taking a growing share of household income (IEA, 2013). The current political crisis in Ukraine and Russia's chess operations with the supply of natural gas, have again emphasized the role of energy as an effective tool to influence international relations and maintaining political influence.

During the last two decades, environmental and security concerns have led to a rapid and far-flung development of renewable energies. Modern wind power development, for example, now is found in over 100 countries, and solar power deployment is - in one form or another - in many more. Reaping the benefits of renewable sources has become a global ambition for several reasons, ranging from anxieties about climate change and energy security to the dangers of the atom. Indeed, the generous feed-in tariffs that Germany used to stimulate renewable energy development have been so effective that Chancellor Merkel was able to renounce Germany's nuclear program after the Fukushima nuclear accident in 2011 (The Economist, 2011). Nonetheless, renewable energy development has been uneven around the world. Despite rapid and substantial growth in countries such as China, Germany, Spain and the United States, it still represents but a small amount of generation in most countries. For this reason, governments still need to consider other options, including cleaner use of fossil fuels, nuclear power, and new technologies such as shale gas fracking.

All energy sources are characterized by potentially negative impacts, direct or indirect, manifesting themselves at different spatio-temporal scales. The economic costs of resources and the reliability of their supply are no longer the only criteria shaping political decisions and public opinions. Rather, perceptions of energy landscapes from renewable energy resources can be significant factors affecting: (1) national energy policies and their support by the general public (Leiserowitz et al., 2013); (2) acceptance of new energy facilities by local communities (Frantál, Kučera, 2009; Frantál, 2014; Pasqualetti, 2011a; Pasqualetti, 2011b; Soland et al., 2013, etc.); and even (3) customer loyalty in liberalized residential energy markets (Hartmann, Ibanez, 2007).

The concept of what we call the "energy landscape" is one of the most intriging, important and challenging themes of the new geography of energy. Energy landscape is a term that has been commonly used for decades in physics and organic chemistry. In recent years, however, it has acquired a new meaning in the field of geography and landscape ecology (Pasqualetti, 2012). An energy landscape is a landscape whose images and functions (be they natural, productive, residential, recreational, cultural, etc.) have been significantly affected by energy development. Traditional energy landscapes include mines, canals, refineries and power plants, transmission lines, well fields and waste disposal sites, but more recently they have come to include expansive, whirling wind turbines and even the glare of solar central receivers in places like Ivanpah Dry Lake California (e.g. Nadai, Van der Horst, 2010; Zimmerman, 2014). In the broadest context, the range of what can be called an energy landscape is particularly expansive, though it may be used in the context of all branches of energy production and consumption with a geographic expression.

Projects like wind farms, solar power plants, the cultivation of energy crops, biogas stations and other innovative technologies, have become effective means of realizing officially declared state-subsidized support for clean and sustainable energy. These projects, as well, can be objects of entrepreneurial interest among investors and developers, a potential source of income for communities involved (often located in less-favoured rural areas), and an alternative type of land use and source of profit for 
farmers. In the eyes of objectors, however, they can also be considered visual polluters of scenic landscapes, degraders of arable land, potential threats to local tourism, and a privileged lobby business thought to be unable to compete without subsidies.

Renewable energy sources - such as wind and some types of solar - are often spatially dispersed, requiring substantial land resources in comparison to conventional energy sources such as coal, oil or gas. For this reason, they may be mostly undertaken in rural areas hitherto unaffected by large-scale industrial development. Only recently the 'brightfield' projects (brownfield lands converted into a newly usable lands by implementation of renewable energy technologies) have been developing (Kunc et al., 2011, 2014). The problem of balancing both the real and perceived advantages and disadvantages of projects (taking into account such diverse considerations as global climate issues, the energy security strategies of national governments, regional development policies and local community economic benefits, while also on the other hand stressing the significance of nature and landscape protection, calling for a restoration of productive farming, and the preservation of local cultural identity), often provokes political and social conflicts arising from differing values and varying conceptions of land use (Boholm, Löfsted, 2004; Devine-Wright, 2011).

As renewable energy projects grow in frequency and scale, new forms of local opposition have emerged, and coal and nuclear power plants are no longer the only energy facilities people do not want built in their backyards. Opposition has increased most rapidly to wind power, but opposition to solar is on the rise as well. So concerned is it to this unwelcome trend that the International Renewable Energy Agency recently formed a group to provide factual balance to many of the misconceptions to renewable energy. It takes the name The Coalition for Action to Bolster Public Support for Renewable Energy (Irena, 2014). Such public responses range from impacts on archaeological sites and desert tortoises to accelerated erosion and visual glare, and they receive substantial attention in the press. At worst, such responses to landscape impacts have provided fodder for those who would wish to slow down renewable energy expansion in favour of maintaining the status quo. Many opponents to solar have been recommending that the development of large solar installations blatantly misses the major advantage of the resource, i.e., that is naturally distributed. They have advocated more distributed installations, such as covered parking, rooftops and community-scale projects.

Attention to the landscape impacts of energy transitions is just one of the many themes catching the attention of academic geographers. The geography of energy has been significantly progressing from being simply just another descriptive sub-discipline of industrial geography that focused on analyzing patterns of energy supply and demand. The new geographies of energy are encompassing all economic sectors, from primary to quaternary, covering a very wide range of current topics beyond the basic economic issues. Problems investigated in this field range from the uneven distribution of primary energy resources and patterns at all scales and the geopolitical impacts of diverging energy policies and international security issues, through to the issues of global climate change, air pollution and sustainable development, land use conflicts and adaptive management strategies within landscape planning and facility siting, problems of agricultural restructuring and food insecurity, including issues of energy poverty and social injustice and the broader socio-cultural contexts of energy transitions, even encompassing topics such as energy literacy and energy education (Solomon, Pasqualetti, 2004; Pasqualetti, 2011c).

Petrova (2014) summarized the recent Annual Meeting of the Association of American Geographers in Tampa, Florida with the title "Energy Geographers Take Over". The 25 paper sessions on the topic of Energy, comprising more than 100 papers presented, indicated that energyrelated topics have increased in importance for both human and physical geographers, demonstrating the growing importance of geography to energy studies. While most of the energy sessions were supported by the AAG Energy and Environment Specialty Group, many papers were presented as a part of thematically broader sessions (e.g., Climate Change and Indigenous People). The energy geography contributions employed many traditional geographical concepts such as spatial fix, material energy flows, metabolism, and territory and territoriality, but also more novel interrogations of infrastructure, assemblages, vulnerability, resilience, community, landscapes, justice, etc. (Petrova, 2014).

The aim of this Special Issue of Moravian Geographical Reports is to contribute to current knowledge and debates about the spatial scales and social dynamics of on-going energy transition processes in the European context, and to highlight the role of geography in identifying and addressing current energy dilemmas. The origin of this issue lies in the international conference on New Trends and Challenges for Energy Geographies, organized by the Institute of Geonics, Academy of Sciences of the Czech Republic in Brno, August 6-8, 2013, in the context of the research project: "Energy Landscapes: Innovation, Development and Internationalization of Research (ENGELA)", Reg. No. ESF OP CZ.1.07/2.3.00/20.0025. This research project was developed with the objective of accelerating international collaboration in the research on emerging energy landscapes. This Special Issue comprises selected, revised and updated original papers from the conference, supplemented by some further contributions. These introductory editorial comments emphasise the key topics and coherence of the overall work.

New energy landscapes are forged when and where energy transitions meet rural transitions. Of course, energy was always part of the rural landscape and economy, but recent decades have seen some profound changes in the way that rural landscapes are utilized, perceived and governed. The European rural landscape is no longer simply the dominion of farming for food (as was the priority in the post-World War 2 era - on both sides of the former Iron Curtain), but is increasingly designed to accommodate alternative or new agricultural and industrial services and tourism activities (Frantál et al., 2013). With Ecosystem Services becoming a mainstream policy narrative (in some countries more quickly than in others), some of these changes are typified as shifts in 'services' provided by specific landscapes towards multifunctional land uses, that include more cultural services (e.g. recreation) or regulating services (e.g. flood control, climate control). Other policy narratives are at play as well and especially popular is the portrayal of renewable energies as an important opportunity for sustainable rural development. There remains the question, however, of the extent to which the political narratives of a new role for farmers as competitive entrepreneurs and "energy producers", accord with farmers' attitudes and their daily practices. 
The papers collected in this volume address many of the core issues in the "landscape - energy nexus", from questions about what a landscape is for, and who has what stake in particular patterns of economic developments related to energy, to measures of efficiency, problems of scalability and questions of governance and justice, in case studies on Europe's energy transitions, old and new.

In the first paper, Charles Warren illustrates - by presenting a case study investigating the attitudes of Scottish farmers to policy proposals for extensive conversion of farmland to perennial crop production - how the networked nature of current energy systems produces "geographies of disconnection". The strong antipathy expressed by most farmers to energy crops exemplifies some of the wider sociopolitical and socio-cultural mismatches and geographical disconnects. Warren's discussion demonstrates that these disjunctions not only affect energy geographies but also raise questions about the ability of current governance structures and liberal democratic systems to deliver effective action in response to current global challenges.

On a related topic, Gerd Lupp, Olaf Bastian, Reimund Steinhäußer and Ralf-Uwe Syrbe explore perceptions of energy crop production as a result of energy policies in Germany. While many German farmers see themselves as being responsible for providing many ecosystem services and prefer a regional scale of energy crop cultivation based on conventional crops, lay people do not consider energy crop production as an important ecosystem service. Rather, they are interested in diverse agricultural landscapes that provide food, wildlife habitat and aesthetics, with at best a minor role for crop residues to be used for bio-energy production.

Over the last few years many European countries have experienced a boom in photovoltaic power plants (PVs), which resulted in controversies related to the economic efficiency and environmental sustainability of solar energy being driven by political interventions (see e.g., Williams, 2010). The very strong spatial and temporal variability of solar resources and subsequent electricity production, poses new challenges for power grid system reliability and predictability. In the paper by Jaroslav Hofierka, Ján Kaňuk and Michal Gallay, recent data on the development of PVs in the Czech Republic and Slovakia are analyzed with a focus on their spatial distribution patterns. Observing that the spatial pattern of adoption of photovoltaic installations does not correlate with the spatial distribution of solar resource potential, their findings demonstrate that the policy is inefficient and that its design opens the door to many individual investment decisions that are not necessarily in the best public interest. They illustrate the ineffective trade-offs between resource policies that are strongly spatially targeted to maximize benefit-cost ratios, and policies that ignore resource geography by offering financial support everywhere, and therefore to every land owner.

One of the most recent, most efficient and environmentally friendly trends in the development of energy sectors in many European countries, is the so-called distributed energy system. The paper by Justyna ChodkowskaMiszczuk discusses small-scale renewable energy systems in the context of the development of distributed generation in Poland. One of the important dimensions of this process is the creation of micro- and small-power producers using renewable, locally available energy sources. The author notes that the development of small-scale renewable energy producers takes place in two ways, which are spatially differentiated. One is through small hydropower plants, which are the aftermath of hydropower development in areas traditionally associated with water use for energy purposes (northern and western Poland), and the second is through other renewable energy sources, mainly biogas and solar energy, primarily in southern Poland in highly urbanized areas.

Austria has long been a European leader in the green economy, excelling in diverse sub-sectors from biomass heating systems to organic farming. The socio-spatial diffusion of clean technologies, however, has not been automatic and without problems, even in this country. The contribution by Markus Seiwald unpacks the notion of the "up-scaling" of successful green technology adoptions, and challenges the underlying assumption that technology diffusion processes follow a linear trend from small-scale pilot plants to industrial-scale facilities. As Seiwald demonstrates through an analysis of the historical development of the Austrian biomass district heating niche, the socio-technical configurations are usually implemented at a variety of scales simultaneously. In a valuable contribution to the literature on energy transitions, he identifies four dominant designs that shape the diffusion dynamics of the technology.

Throughout modern history, coal has played a key role in human development and it still vitally powers global electric grids. Coal-powered development, however, has come with tremendous environmental and social costs. As emphasized by McKibben (2003, cited in Freese, 2003), given the particular chemistry of global warming, it is possible that the decisions we make about coal in the next two decades may prove to be more important than any decisions we have ever made as a species. The paper by Bohumil Frantál and Eva Novaková explores the long-term 'unintended' regional consequences of coal energy production in the Czech Republic, in terms of the 'environmental injustice' and 'resource curse' theories. Their empirical case study identified significant associations between the spatially uneven distribution of coal power plants and indicators of environmental and socio-economic quality of life (including population vital and health statistics, socioeconomic well-being and social capital indicators), as well as recent development trends.

In the final paper, Dan van der Horst makes the case for a counterfactual geography of energy, inviting geographers to use their imaginations to project a view of their geographical area as if it was performing just like the 'best practice' cases found in the world today. He argues that this comparative analysis of the relative underperformance of "our bit" of the planet can serve to highlight the unacceptable nonsustainability of our current status, to familiarise ourselves with the normality of better practices found elsewhere right now, and to 'nudge' us into becoming more creative and ambitious in seeking to achieve a transition to a society that does not externalise its greenhouse gas emissions for the disbenefit of future generations.

In summary, the world has changed since Chapman (1961) promulgated a "Geography of Energy" as essential for Geography as a discipline, in terms of its potential contributions to society, writ large. In the intervening fifty years or so, the investigations of energy landscapes recently have provided many important and useful insights into the geographic and socio-political effects of societal change with respect to energy, at once narrowing the focus to specific locales and at the same time acknowledging the overwhelming importance of the global grounding of 
local response. The contributions to this Special Issue of the Moravian Geographical Reports illustrate both the theoretical and empirical aspects of these important politicoeconomic and socio-spatial changes over the last fifty years, and of the responses to such changes by geographers.

In summary, Geography as a discipline has changed, to reflect the world as inhabited - but also the world as desired.

\section{References:}

BOHOLM, A., LÖFSTED, R. [eds.] (2004): Facility sitting: Risk, Power and Identity in Land Use Planning. London, Earthscan, 229 pp.

CHAPMAN, J. D. (1961): A Geography of Energy: An Emerging Field of Study. The Canadian Geographer, Vol. 5, No. 1, p. 10-15.

DEVINE-WRIGHT, P. [ed.] (2011): Renewable Energy and the Public. London, EarthScan, 336 pp.

DORIAN, J. P., FRANSSEN, H. T., SIMBECK, D. R. (2006): Global challenges in energy. Energy Policy, Vol. 34, No. 15 , p. 1984-1991.

FLORINI, A., SOVACOOL, B. K. (2009): Who governs energy? The challenges facing global energy governance. Energy Policy, Vol. 37, No. 12, p. 5239-5248.

FRANTÁL, B. (2014): Have local government and public expectations of wind energy project benefits been met? Implications for repowering schemes. Journal of Environmental Policy \& Planning. DOI:10.1080/152390 8X.2014.936583.

FRANTÁL, B., KUČERA, P. (2009): Impacts of the operation of wind turbines as perceived by residents in concerned areas. Moravian Geographical Reports, Vol. 17, No. 2, p. $34-45$.

FRANTÁL, B., MARTINÁT, S., HALFACREE, K., WALKER, G., WOLSINK, M., VAN DER HORST, D., MAYE, D., DAX, T., HALL, C. M., CLARK, G., KUNC, J., PETR, O., ŠAUER, M., TONEV, P., VYSTOUPIL, J. (2013): New Rural Spaces: Towards Renewable Energies, Multifunctional Farming, and Sustainable Tourism. Brno, Institute of Geonics, $157 \mathrm{pp}$.

FREESE, B. (2003): Coal: A Human History. Cambridge: Basic Books, 320 pp.

HARTMANN, P., IBÁŃEZ, V. (2007): Managing customer loyalty in liberalized residential energy markets: The impact of energy branding. Energy Policy, Vol. 35, No. 4, p. 2661-2672.

IEA (2013): World energy outlook. [online] [cit. 05.06.2014]. Available at: http://www.worldenergyoutlook.org/ publications/weo-2013/

IRENA (2014): Coalition for Action to Bolster Public Support for Renewable Energy. [online] [cit. 01.11.2013]. Available at: http://www.irena.org/DocumentDownloads/ Publications/Coalition\%20Flyer\%20Single\%20Pages.pdf

KUNC, J., FRANTÁL, B., KLUSÁČEK, P. (2011): Brownfields as places for renewable sources location? In: Klimová, V., Zitek, V. [eds.]: $14^{\text {th }}$ International Colloquium on Regional Sciences Location: Boretice, Czech Republic, June 22-24, 2011, pp. 132-140. WOS: 000312552500014
KUNC, J., MARTINÁT, S., TONEV, P., FRANTÁL, B. (2014): Destiny of urban brownfields: Spatial patterns and perceived consequences of post-socialistic deindustrialization. Transylvanian Review of Administrative Sciences, Vol. 41, p. 109-128.

LEISEROWITZ, A., MAIBACH, E., ROSER-RENOUF, C., FEINBERG, G., MARLON, J., HOWE, P. (2013): Public support for climate and energy policies in April 2013. New Haven, Yale University and George Mason University.

NADAI, A., VAN DER HORST, D. (2010): Landscapes of Energies. Landscape Research, Vol. 35, No. 2, p. 143-155.

OECD (2013): Global energy challenges. OECD Observer No. 295 Q2 2013 [online]. [cit. 05.06.2014]. Available at: http://www.oecdobserver.org/m/fullstory.php/aid/4120/ Global_energy_challenges.html

PASQUALETTI, M. (2011a): Opposing Wind Energy Landscapes: A Search for Common Cause. Annals of Association of American Geographers. Vol. 101, No. 4, p. 907-917.

PASQUALETTI, M. J. (2011b): Social Barriers to Renewable Energy Landscapes. Geographical Review, Vol. 101, No. 2, p. 201-223.

PASQUALETTI, M. J. (2011c): The Geography of Energy and the Wealth of the World. Annals of the Association of American Geographers, Vol. 101, No. 4, p. 971-980.

PASQUALETTI, M. (2012): Reading the Changing Energy Landscape. In: Stremke, S., Van Den Dobbelsteen, A. (eds.): Sustainable Energy Landscapes: Designing, Planning, and Development. Boca Raton, Florida, CRC Press, pp. 11-44.

PETROVA, S. (2014): The AAG in Tampa: Energy Geographers take over. [online] [cit. 05.06.2014]. Available at: http://urban-energy.org/2014/04/21/ energyaag2014/

SOLAND, M., STEIMER, N., WALTER, G. (2013): Local acceptance of existing biogas plants in Switzerland. Energy Policy, Vol. 61, p. 802-810.

SOLOMON, B. D., PASQUALETTI, M. J. (2004): History of energy in geographic thought. In: Cleveland, C. [ed.]: Encyclopedia of Energy. Vol. 2, p. 831-842. San Diego, Elsevier.

The Economist (2011): Nuclear power? No thanks (again). The Economist. March 15, 2011. [online] [cit. 05.06.2014]. Available at: http://www.economist.com/node/21016899

WILLIAMS, D. (2010): Czech Republic: A Dark Spot in a Sunny Business. Renewable Energy World. [online] [cit. 05.06.2014]. Available at: http://www. renewableenergyworld.com/rea/ news/article/2010/12/ czech-republic-a-dark-spot-in-a-sunny-business

ZIMMERMAN，J. (2014): IVANPAH: Pilots complain of solar plant glare. [online] [cit. 05.06.2014]. Available at: http://www.pe.com/local-news/local-news-headlines/ 20140314-ivanpah-pilots-complain-of-solar-plant-glare.ece

ZIMMERER, K. (2011): New Geographies of Energy: Introduction to the Special Issue. Annals of the Association of American Geographers. Vol. 101, No. 4, p. $705-711$. 


\section{Authors' addresses:}

RNDr. Bohumil FRANTÁL

Institute of Geonics, ASCR, v. v. i. - Department of Environmental Geography

Drobného 28, 60200 Brno, Czech Republic

e-mail: frantal@geonika.cz

Prof. Martin J. PASQUALETTI

School of Geographical Sciences and Urban Planning, Arizona State University

P.O. Box 875302, Tempe, AZ 85287-5302, USA

e-mail:pasqualetti@asu.edu

Dr. Dan VAN DER HORST, Ph.D.

Research Institute of Geography and the Lived Environment

School of GeoSciences, University of Edinburgh

Drummond Street, Edinburgh EH8 9XP, UK

e-mail: Dan.vanderHorst@ed.ac.uk

\section{Please cite this article as:}

FRANTÁL, B., PASQUALETTI, M. J., VAN DER HORST, D. (2014): New trends and challenges for energy geographies: introduction to the Special Issue. Moravian Geographical Reports, Vol. 22, No. 2, p. 2-6. DOI: 10.2478/mgr-2014-0006. 